\title{
Fatal variceal haemorrhage after paracetamol overdose
}

\author{
J R THORNTON AND M S LOSOWSKY \\ From the Department of Medicine, St James's University Hospital, Leeds
}

\begin{abstract}
SUMmary A patient is described where oesophageal varices developed and bled 13 days after a paracetamol overdose. The bleeding was unresponsive to medical management and proved fatal. There was no evidence that the patient had pre-existing liver disease. At necropsy the liver showed severe acute parenchymal necrosis but chronic lesions were absent. The portal vein and hepatic veins were patent.
\end{abstract}

\section{Case report}

A 43 year old. previously healthy man was transferred from another hospital having taken an overdose of $50-100 \times 500 \mathrm{mg}$ paracetamol tablets four days earlier. No alcohol was taken with the overdose and the patient usually drank two or three pints of beer per week. On arrival in Leeds, he was confused and aggressive because of grade III hepatic encephalopathy. There were no stigmata of chronic liver disease and neither the liver nor spleen were palpable. $\mathrm{He}$ was transferred to intensive care, sedated and ventilated. An intracranial pressure monitor was inserted and the pressure found to be satisfactory at $8-10 \mathrm{~cm}$ water. His prothrombin time ratio was 7.5 times normal and alanine aminotransferase 13600 IU/l. He was anuric and his plasma creatinine was considerably raised at $560 \mu \mathrm{mol} / \mathrm{l}$. Intermittent haemofiltration was therefore started and continued for four hours each day. Serum autoantibodies, $\mathrm{HBsAg}$, hepatitis A IgM and other viral studies were all negative. Serum copper, caeruloplasmin and $\alpha-1$ antitrypsin were normal.

Four days later, he developed pneumococcal pneumonia, and this responded well to treatment. At 11 days after his overdose, his intracranial pressure and arterial pressure remained satisfactory. His

Address for correspondence: Dr J R Thornton. Dept of Medicine. St Jamesis University Hospital. Leeds LS9 7TF

Accepted for publication 17 Fehruary 1989. sedation was reduced and he began to breathe spontaneously. He was passing approximately $800 \mathrm{ml}$ urine daily though his plasma creatinine remained high at $710 \mu \mathrm{mol} / \mathrm{l}$. He had become more jaundiced with a plasma bilirubin of $326 \mathrm{umol} / \mathrm{l}$.

Thirteen days after his overdose, he had a considerable haematemesis. At this time, his prothrombin time ratio had improved to $1 \cdot 6$. His platelet count was $118 \times 10^{\prime \prime} / 1$. Upper gastrointestinal endoscopy was done and revealed a single, very large, blue varix present in the distal $15 \mathrm{~cm}$ of the oesophagus. A large fresh clot with active bleeding from the edges was present on the varix. No bleeding lesion was seen in the stomach or proximal duodenum. The varix was injected with sclerosant, but the bleeding continued. A Linton tube was inserted and the patient was transfused with fresh frozen plasma and whole blood. Unfortunately, he had further fresh haematemeses. A glypressin infusion was started, but failed to halt the bleeding. The next day, the Linton tube was removed and a further endoscopy done. The oesophageal varix was seen to be still bleeding and was again injected with sclerosant. A Sengstaken tube was inserted. He had further fresh haematemeses, however, and by this time had required the transfusion of 4.51 blood. It was decided, therefore to carry out an oesophageal transection. At operation he was found to have varices around the cardia and distal oesophagus. The lower oesophagus was transected. There was approximately 1.51 blood 
present in the abdomen arising from a recent tear of the lower pole of a normal sized spleen. The liver was described as pale, firm and non-cirrhotic. There was no ascites. The spleen was removed. It weighed 188 g. Unfortunately, bleeding continued from large gastric and para-oesophageal veins near the hiatus and he exsanguinated on the operating table.

At necropsy the portal vein and hepatic veins were found to be patent. No unusual cause of oesophageal varices such as mediastinal fibrosis was found. No ulceration or erosions were found in the stomach or duodenum. Cerebral and pulmonary oedema were present. Histology of the liver showed a uniform, severe acute parenchymal necrosis with a minimal inflammatory infiltrate. Cirrhosis, fibrosis, and focal nodular lesions were absent. There was no central hyaline sclerosis or other features indicative of high alcohol intake.

Catecholamines were measured in a suitably collected plasma sample' which had been taken the day before the patient's first haematemesis. Both plasma adrenaline $(760 \mathrm{pg} / \mathrm{ml})$ and noradrenaline $(1720 \mathrm{pg} / \mathrm{ml})$ were very high compared with values previously found in resting healthy subjects (adrenaline : median $55 \mathrm{pg} / \mathrm{ml}$, range 20-165; noradrenaline : median $295 \mathrm{pg} / \mathrm{ml}$, range 155-795) and also much greater than the median values (adrenaline: $140 \mathrm{pg} /$ $\mathrm{ml}$, noradrenaline $900 \mathrm{pg} / \mathrm{ml}$ ) previously found in patients with cirrhosis and varices which had previously bled.'

\section{Discussion}

This case illustrates the rapidity with which oesophageal varices may occasionally arise. Because there were no indications that the patient had preexisting hepatic disease, the varices would appear to have developed and begun to bleed only 13 days after the onset of liver damage. The oesophageal varix seen endoscopically in this patient was unlike typical varices seen in association with cirrhosis. In contrast, it was very large and appeared very thin walled and very blue. Whether the patient's presumed portal hypertension contributed to the rupture of his spleen is uncertain.

Portal hypertension may occur in severe, acute viral hepatitis ${ }^{2}$ but portal pressure is usually normal or only slightly raised in more benign cases. ${ }^{-11}$ Nouel and colleagues described one case of fulminant, presumed viral hepatitis (HBsAg negative) who had ascites and suffered a large haematemesis. Endoscopy was not performed but, at necropsy oesophageal varices were discovered and no other potential bleeding site was apparent, the portal vein was patent and the liver was not cirrhotic.

The most likely causes of our patient's presumed portal hypertension were the gross architectual distortion of his liver caused by severe parenchymal necrosis and altered hepatic haemodynamics as a result of his very high plasma catecholamines. ${ }^{1 " n}$

In conclusion, variceal haemorrhage is a rare complication of severe, acute liver disease.

\section{References}

1 Thornton JR. Dean HG, Losowsky MS. Do increased catecholamines and plasma methionine enkephalin in cirrhosis promote blecding oesophageal varices? $Q \mathrm{~J}$ Med 1988: 67: 541-.51.

2 Lebrec D. Nouel O. Bernua J. Rueff B. Benhamou JP. Portal hypertension in fulminant viral hepatitis. Gut 1980: 21: $962-4$.

3 Reichman S. Davis WD. The splenic approach to the portal circulation. Intrasplenic and intrahepatic tissue pressure measurements in acute and convalescent hepatitis. Gastroenterology 1957: 33: 609-15.

4 Hacrter W. Palmer ED. Portal hypertension with esophageal varices in acute infectious hepatitis: further observations. Am J Med Sci 1959: 237: 596-9.

5 Preisig R. Rankin JG, Sweeting J, Bradley SE. Hepatic hemodynamics during viral hepatitis in man. Circulation 1966: 34: 188-97.

6 Lundbergh P. Strandell T. Changes in hepatic circulation at rest, during and after exercise in young males with infectious hepatitis compared with controls. Acta Med Scand 1974: 196: 315-25.

7 Nouel O, Lebrec D, Denis J. Rupture de varices oesophagiennes chez un malade atteint dhepatite fulminante. Gastroenterol Clin Biol 1981; 5: 91-2.

8 Willett IR. Esler M. Jennings G. Dudley FJ. Sympathetic tone modulates portal venous pressure in alcoholic cirrhosis. Lancet 1986: ii: 939-43.

9 Moreau R, Lee SS, Hadengue A, Braillon A. Lebrec D. Hemodynamic effects of a clonidine-induced decrease in sympathetic tone in patients with cirrhosis. Hepatology 1987: 7: 149-54. 